\title{
Development of Teaching Materials for Elementary School Statistics Material Based on Higher-Order Thinking Skills
}

\author{
Budi Prihartini ${ }^{1}$, Santoso $^{2}$, Sri Utaminingsih ${ }^{3}$ \\ \{prihartinibudi@gmail.com ${ }^{1}$,santoso.bkumk@gmail.com², sri.utaminingsih@umk.ac.id ${ }^{3}$ \} \\ 1,2,3Basic Education Master Study Program, Student at Post-Graduate of primary teacher education, \\ Universitas Muria Kudus, Indonesia
}

\begin{abstract}
This study was designed to describe and study Mathematics teaching materials based on higher-order thinking skills assisted by Media Karpinkas statistical material for elementary school students in Jepara Regency. The development procedure was adapted from Borg and Gall which involved three stages, namely preliminary study, development, ability test. Published validation, expert, field, and implementation. The research method uses quantitative and qualitative methods. The research data were obtained from questionnaires, observations, tests, and documentation in ten schools in Jepara Regency. During learning, students are more active and happy to use Media Karpinkas to learn while playing. Results Processing the data shows the posttest value of the experimental class is higher than the control class. The pretest and posttest t-test results were 17.9. The $\mathrm{t}$-test results of the questionnaire are known to bet count $1.012<\mathrm{t}$ table 1.972. Thus it can be denied that teaching materials for elementary school based on higher-order thinking skill worty in learning mathematics.
\end{abstract}

Keywords: Development of Teaching Materials, Higher-Order Thinking Skill, Statistics

\section{Introduction}

Statistics is one of the elementary school mathematics teaching materials. According to Permendikbud No. 37 of 2018 about Core Competencies and Basic Competencies in the 2013 curriculum, statistics are taught since third grade. As a prerequisite for elementary school statistics, it is certainly expected to provide the right concept planting. Even though the thirdgrade material is integrated with thematic learning. Therefore, to focus on elementary school statistics material it is necessary to develop teaching materials. Prastowo (2012: 16-19) teaching materials is the main problem that cannot be ruled out in a unified whole discussion on how to make teaching materials. The quality of learning becomes low when educators are only fixated on conventional teaching materials without any creativity to develop these teaching materials innovatively. The development of teaching materials that are by the mandate of the 2013 curriculum is one of them is teaching materials based on higher-order thinking skills.

Gazali (2016) teachers should prepare teaching materials that contain learning activities contained in teaching materials that should be related to daily life and are designed as fun activities for students and can choose learning strategies and approaches that fit the conditions in school. Mulyana (2012) the making of teaching materials is not only based on estimates or 
assumptions from the instructors, which is assumed students will learn through certain learning trajectories, but the making of teaching materials is intended as one of the solutions to solve these problems.

Linkage to higher-order thinking skills, Cambridge English Teaching Knowledge test, The University of Cambridge (2015), high-level thinking skills is cognitive skills that teachers can teach their students. These skills include analysis and evaluation, where students are taught to make creative problem-solving decisions. Nugroho, (2010: 17) based on learning objectives in class, HOTS is categorized among others; HOTS as transfer (HOTS as a transfer), HOTS as critical thinking (HOTS as critical thinking), HOTS as problem-solving (HOTS as problemsolving). Amir (2018) in improving the metacognition ability of elementary school students needs to be developed teaching materials based on contextual problem-solving. This can be a solution to improve students' metacognition abilities because in solving contextual problems, students do stages of problem-solving by arousing prior knowledge that has been associated with the context of the problem which is then linked to formal knowledge learned previously.

Nugroho (2018: 18) HOTS as problem-solving is defined as the skill of identifying problems and solving problems using nonautomatic strategies. With this ability, students will be able to solve their problems and work more effectively. Anggo (2011: 25) learning mathematics that presents problem-solving can lead students to develop abilities that are building new knowledge, solving various context problems, applying various strategies, and reflecting on the problem-solving process. Ardya (2018) well-designed learning can develop critical thinking skills. Critical thinking skills are important for students. The ability to think critically can help students analyze ideas or ideas. Critical thinking skills are needed for students to analyze because they can face global challenges.

In developing this teaching material also uses learning media. Arsyad (2013: 69) factors that must be considered in choosing media, among others are 1) barriers to development and learning including funds, facilities, and equipment available, time, resources (human and material). 2) content requirements, assignments, and types of learning. 3) obstacles from the student's side should consider the ability and initial skills and other characteristics of students. 4 ) other considerations such as the preferences of institutions, teachers and students and costeffectiveness. Sundayana (2014: 28) explained that Mathematics media is a vehicle for learning information channeling, where information in Mathematics learning aims to make abstract concepts and symbols of Mathematics concrete under students' level of thinking. From the above explanation, it can be concluded that the media is an intermediary and a tool to construct contextual problems. Media in learning mathematics can foster mathematical creativity.

Mathematics is one of the subjects that students are not interested in. Though mathematics is a subject that is indicated as important in the change of human civilization. Firdaus (2015: 81) Mathematics is a universal science that underlies the development of technology and has an important role in various disciplines and can advance human thought. Wijaya, (2012: 5-6) Adam \& Hamm mentioned four kinds of views about the position and role of mathematics, namely: 1) mathematics as a way to think. Logical and systematic thinking, 2) mathematics as an understanding of patterns and relationships. In learning mathematics, students need to connect mathematical concepts with the knowledge they already have, 3) mathematics as a tool. An example of this mathematical application is the concept of one-on-one correspondence which underlies the development of numbers, 4) mathematics as a language. Mathematical symbols have the same meaning for various terms from different languages.

NCTM (2000) school mathematics learning is learning that develops students' mathematical power through mathematical content standards that are taught by teachers in the 
form of Basic Competencies as a path or media in developing reasoning, connection, problemsolving, communication and representation. Math power is the basic ability for students to be able to have high thinking skills. Sumarni (2018: 11) the process to develop this mathematical power can be done by the teacher to make qualified planning because in processing Basic Competence, the teaching material must be planned as learning media which includes the process of exploration, conjecture or conjecture, generalization, and verification.

\section{Method}

This type of research is research and development that adopts from Borg and Gall with a ten-step. The stages are simplified into three steps, namely introduction, development, and testing. Setyosari (2016: 292-293) to produce products, materials or designs as a research and development cycle. Sources of data in this study include students, teachers, and media experts and learning material experts. This research was conducted in ten elementary schools in Jepara Regency. Data collection techniques through questionnaires, observation, pretest, and posttest.

\section{Results and Discussion}

The validation of the development of teaching materials on elementary school statistics material based on higher order thinking skills includes product validation by media experts and material validation. The percentage criteria for validation results can be seen in the following table.

Table 1 : Percentage Criteria

\begin{tabular}{|c|c|l|}
\hline Percentage (\%) & Mean Level & \multicolumn{1}{|c|}{ Score } \\
\hline $84-100$ & 5 & Very effective / feasible / appropriate \\
\hline $68-84$ & 4 & effective / feasible / appropriate \\
\hline $52-68$ & 3 & Fairly effective / feasible / appropriate \\
\hline $36-52$ & 2 & Not effective / appropriate / appropriate \\
\hline$-\quad 36$ & 1 & Very ineffective/ appropriate/ appropriate \\
\hline
\end{tabular}

The results of the hypothetical model validation to test the effectiveness of the development model that will be carried out. The hypothetical model test was carried out by two experts. The results of the test of the effectiveness of the hypothetical model are used to conduct research and development on teaching materials of elementary school statistics based on higher-order thinking skills. Eligibility in the hypothetical model if the results obtained score $52-68 \%$ with an average score of 3 and are categorized accordingly.

The results of product validation by media experts were carried out by two experts. Product validation by media experts aims to determine the feasibility of the product development of elementary school statistical material teaching materials based on high-level thinking skills. After obtaining the results of product validation by the media expert in the form of teaching materials, further improvements will be made according to the evaluator's instructions or suggestions. Teaching material products based on high-level thinking skills

The results of product validation by material experts were carried out by two experts. The validation instruments include statements related to high-level thinking skills-based learning in elementary school statistics material. Material high-level thinking skills in elementary school statistics teaching materials in the form of display problems to develop higher-level thinking skills. One ability to improve higher-order thinking skills is by presenting open-ended questions. 
Arifin (2017) learning high-level thinking skills are needed to measure, know the readiness and abilities of students one of them with critical thinking skills. The ability to think critically can be done by giving problems. Contextual problems aim to provide critical and creative thinking exercises when dealing with problems. This is reinforced by the opinion of Conklin (2012), about the characteristics of higher-order thinking skills "characteristics of higher-order thinking skills: higher-order thinking skills encompass both critical thinking and creative thinking". Characteristics of higher-order thinking skills include critical thinking and creative thinking. Critical and creative thinking are two basic abilities in humans because critical thinking and creative thinking can encourage someone to look at and understand the problems that can be faced critically. Also, someone also tries to find a solution creatively. Thus a person gets a new thing that is better and useful for his life.

The assessment of the use of statistical material based on higher-order thinking skills was practiced in ten elementary schools in Jepara Regency. Implementation of the use of statistical material based on higher-order thinking skills by planning learning preparations such as lesson plans and activity sheets contained in the teaching materials of elementary school statistics based on higher-order thinking skills.

The results of product validation by media experts, material experts, and also the implementation of the use of teaching materials for elementary school statistics based on highlevel thinking skills are said to be valid if there is a link between the components of content validity and product validity. Plomp (2013: 29) products are said to be valid if the product components are based on the principle of knowledge called content validity. Then, the components must be related to each other or referred to as construct validity. Product validation is also carried out on content, language, presentation, and graphics.

Based on the explanation, the teaching material of elementary school statistics based on high-level thinking skills can be declared feasible if the components of content validity and construct validity are interrelated, the average score is 3 or at a percentage of $52 \%$ to $68 \%$ with the proper category used.

\section{Discussion}

The effectiveness test of teaching material development is carried out by researching ten elementary schools in Jepara Regency. The study design uses the Prates-post-test control group (pretest-Posttest Control Group Design) research design. Setyosari (2016: 213) pretestposttest control group design research design was an experimental design because both groups were selected according to the criteria required by the study. both groups were given prates. Both groups are treated differently. The groups that were treated differently or not treated were called the control groups. After the implementation of the treatment in the experimental group is completed, then both of them will get a post-test or post-test measurement.

The effectiveness test results are said to be effective if there are differences in the results of the pretest and posttest in the control class and also the experimental class. If the value in the experimental class is higher than the control class it can be said to be effective. Sarmidi (2012) is said to be effective if there are significant differences between the control class and the experimental class. 


\section{Conclusions}

Based on the results of research and development of teaching materials of elementary school statistics material based on high-level thinking skills, it can be concluded that teaching material is said to be feasible if it meets the criteria by obtaining a percentage of $52 \%$ to $68 \%$ with enough categories so that it is suitable for use in learning. The development of statistical material based on high-level thinking skills is said to be effective if there is a higher value difference in the experimental class than in the control class.

\section{Suggestion}

For teachers to develop teaching materials following the applicable curriculum, the needs of teachers and students. Development of teaching materials is also adjusted to the characteristics of students. Students should use teaching materials developed by the teacher to facilitate the interaction of learning, so that learning will be more uplifting and enjoyable.

\section{Thank-you note}

Thank you to the Kemesristek Dikti for providing funding for this thesis research. Thank you to the Head of Master of Education PGSD UMK. Thank you to the supervisor who provides direction guidance so that you can complete the thesis report on time.

\section{References}

[1] Prastowo, Andi. : Panduan Kreatif membuat bahan Ajar Inovatif. Menciptakan Metode Pembelajara yang Menarik dan menyenangkan. Yogyakarta: Diva Press. (2012)

[2] Gazali, Rahmita Yuliana. Pengembangan Bahan Ajar Matematika untuk Siswa SMP Berdasarkan Teori Belajar Ausubel. Jurnal Pendidikan Matematika, 11, (2), 182192.(2016)

[3] Mulyana, Tatang. Pengembangan Bahan Ajar Melalui Penelitian Desain. Infinity. . 2 (1)126-137. (2018)

[4] Nugroho, Arifin. R. 2018. HOTS Kemampuan Berpikir Tingkat Tinggi: Konsep, Pembelajaran, Penilaian, dan Soal-soal. Jakarta: Grasindo. (2018)

[5] Anggo. Pemecahan masalah matematika kontekstual untuk meningkatkan kemampuan metakognisi siswa. Edumatical Journal Pendidikan Matematika, Vol.1, No.02, hlm.35-42. (2011)

[6] Ardya Harditama Putr, Rizki. Pengaruh Model Problem Based Learning Terhadap Kemampuan Berpikir Kritis Ditinjau Dari Motivasi Berprestasi Kelas XI SMAN 1 Ngadirojo. http://karyailmiah.um.ac.id/index.php/Geografi/article/view/73267. 24 Agustus 2018. Diunduh pukul 14.06 WIB (2018).

[7] Arsyad, A. Media pembelajaran, jakarta: Rajawali Pers. (2013)

[8] Firdaus, Fery M. Pembelajaran Matematika Realistik untuk Meningkatkan Kemampuan Pemecahan Masalah Matematis Siswa Sekolah Dasar. Jurnal Pedagogik Vol. III, No. 1, (2) (2015)

[9] Wijaya, Ariyadi. Pendidikan Matematika Realistik. Suatu Alternatif Pendekatan Pembelajaran Matematika. Yogyakarta: Graha Ilmu. (2012)

[10] Fathani, Abdul H. Pengembangan Literasi Matematika Sekolah Dalam Perspektif Multiple Intelligences. Edu Sains Volume 4 Nomor 2;(2016) 
[11] Arifin, Zaenal. Mengembangkan Instrumen Pengukur Critical Thinking Skills Siswa pada Pembelajaran Matematika Abad 21. Jurnal THEOREMS (The Original Research of Mathematics) Vol. 1 No. 2, Januari 2017 hal. 92-100

[12] Conklin, W.Higher-order thinking skills to develop 21st century learners. Huntington Beach: Shell EducationalPublishing, Inc. (2012).

[13] Plomp, tjeerd dan Nieveen, Nienke..Educational Design Research. Netherland: Institute Curriculum for Development (2013)

[14] Setyosari, Punaji. Metode Penelitian Pendidikan dan Pengembangan. Jakrata: Pranadamedia Group. (2016)

[15] Sarmidi. Efektifitas Strategi Peta Konsep (Mind Map) Dalam Pembelajaran Listrik Otomotif Di Kelas XI SMK Muhammadiyah Prambanan. Skripsi. (2012) 